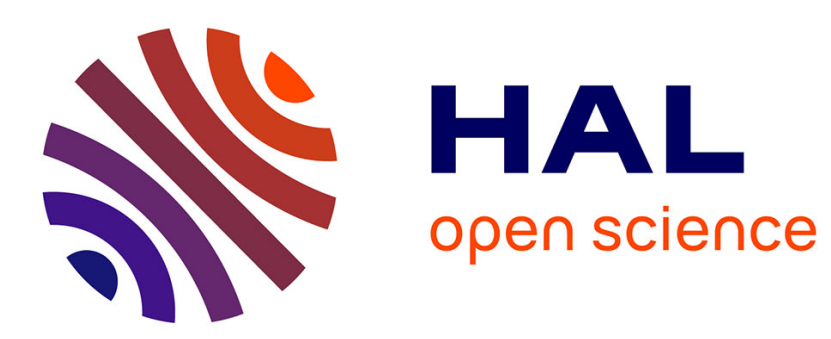

\title{
Identification of Estrogen-Like Alkylphenols in Produced Water from Offshore Oil Installations
}

\author{
Stepan Boitsov, Svein A. Mjøs, Sonnich Meier
}

\section{To cite this version:}

Stepan Boitsov, Svein A. Mjøs, Sonnich Meier. Identification of Estrogen-Like Alkylphenols in Produced Water from Offshore Oil Installations. Marine Environmental Research, 2007, 64 (5), pp.651. 10.1016/j.marenvres.2007.07.001 . hal-00562986

\section{HAL Id: hal-00562986 \\ https://hal.science/hal-00562986}

Submitted on 4 Feb 2011

HAL is a multi-disciplinary open access archive for the deposit and dissemination of scientific research documents, whether they are published or not. The documents may come from teaching and research institutions in France or abroad, or from public or private research centers.
L'archive ouverte pluridisciplinaire HAL, est destinée au dépôt et à la diffusion de documents scientifiques de niveau recherche, publiés ou non, émanant des établissements d'enseignement et de recherche français ou étrangers, des laboratoires publics ou privés. 


\section{Accepted Manuscript}

Identification of Estrogen-Like Alkylphenols in Produced Water from Offshore

Oil Installations

Stepan Boitsov, Svein A. Mjøs, Sonnich Meier

PII:

S0141-1136(07)00089-X

DOI:

10.1016/j.marenvres.2007.07.001

Reference:

MERE 3134

To appear in:

Marine Environmental Research

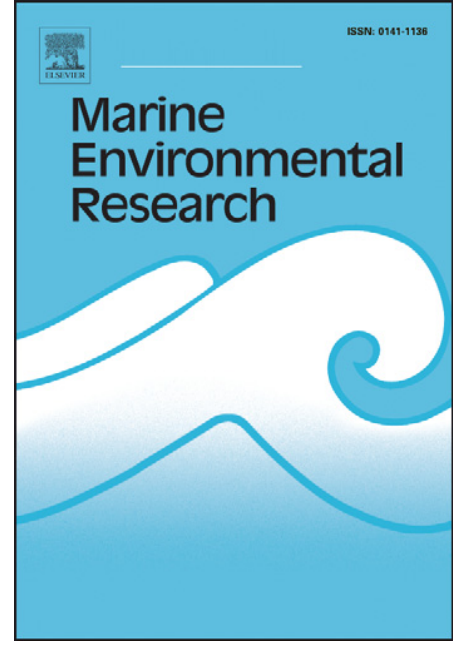

Received Date: $\quad 27$ February 2007

Revised Date: $\quad 28$ June 2007

Accepted Date: $\quad 2$ July 2007

Please cite this article as: Boitsov, S., Mjøs, S.A., Meier, S., Identification of Estrogen-Like Alkylphenols in Produced Water from Offshore Oil Installations, Marine Environmental Research(2007), doi: 10.1016/j.marenvres. 2007.07.001

This is a PDF file of an unedited manuscript that has been accepted for publication. As a service to our customers we are providing this early version of the manuscript. The manuscript will undergo copyediting, typesetting, and review of the resulting proof before it is published in its final form. Please note that during the production process errors may be discovered which could affect the content, and all legal disclaimers that apply to the journal pertain. 


\section{ACCEPTED MANUSCRIPT}

1 Identification of Estrogen-Like Alkylphenols in Produced Water from Offshore Oil

2 Installations

$3 \quad$ Stepan Boitsov, ${ }^{1, *}$ Svein A. Mjøs ${ }^{2}$ and Sonnich Meier ${ }^{1}$

4

$5 \quad$ 1. Institute of Marine Research (IMR), Bergen, Norway

6 2. Norwegian Institute of Fisheries and Aquaculture Research (NIFAR), Bergen, Norway

7 Abstract

8 Produced water released into the sea from oil installations contains a vast number of organic compounds. This work focuses on the analysis and identification of phenols in produced water, in particular long-chain para-substituted alkylphenols, which act as endocrine disruptors for marine biota. Some alkylphenol standards, unavailable commercially, have been synthesised and some compounds of interest identified. However, a complete identification is not possible since conventional GC techniques cannot achieve the desired degree of separation. An overview of the levels of the 52 known alkylphenols in produced water from 9 oil installations in the North and Norwegian Seas has been made. The previously unidentified alkylphenols in produced water have been characterised by means of alkylphenol retention indices (APRI) and mass spectrometry, and their total amounts estimated for the same 9 locations. Our results confirm the presence of naphthols and other as yet unidentified compounds in produced water, while thiophenols were not detected by the used technique.

Keywords: Produced water; alkylphenols; endocrine disruptors; isomers; GC-MS; retention indices; APRI

\section{Introduction}

In oil exploration activities, produced water is the water that comes up with oil from sea bed reservoirs, and is then separated from the oil and released into the marine environment. The quantities are large $\left(147 \times 10^{6} \mathrm{~m}^{3}\right.$ from Norwegian offshore oil activities in 2005) and ever increasing due to a larger water content in maturating production wells. The cited 2005 releases are $4 \times 10^{6} \mathrm{~m}^{3}$ higher than those in 2004 (NPD, 2006). Total releases from all national sectors throughout the North Sea are larger still, having reached $560 \times 10^{6} \mathrm{~m}^{3}$ already in 2002 (Thomas et al., 2004a). The water released in the Norwegian sector each year contains tens of thousands of tonnes of organic compounds, including hundreds of tonnes of alkylphenols (OLF, 2006). Alkylphenols are potential endocrine disruptors, and are thus recognized as a

\footnotetext{
${ }^{*}$ To whom the correspondence is to be addressed. Fax: +47-55238555, email: stepan.boitsov@imr.no
} 
matter of concern for marine biota (Nimrod and Benson, 1996; Meier et al., 2007). Produced water has been shown to contain estrogen receptor agonists, and alkylphenols have been identified as major contributors to this effect (Thomas et al., 2004a,b).

A sensitive and selective method for determination of alkylphenols in produced water has recently been described (Boitsov et al., 2004). The method is based on solid-phase extraction with derivatisation by pentafluorobenzoyl chloride and gas chromatography-mass spectrometry (GC-MS) analysis of the derivates using negative ion chemical ionisation, NCI. The method has detection limits at low ng/l level and now uses 52 alkylphenols of different chain length, from phenol $\left(\mathrm{C}_{0}\right)$ to nonylphenol $\left(\mathrm{C}_{9}\right)$, as standards. However, a large number of alkylphenols are found in an average produced water sample. Theoretically, hundreds of isomers may be present. Most of these are not commercially available and have not been identified.

The primary aim of this work has been to help determine the endocrine-disrupting potential of produced water, since only some alkylphenol isomers have been shown to exert this effect. Namely, long-chain, branched (especially tertiary) para-substituted alkylphenols have the strongest xenoestrogen effect, 4-tert-octylphenol being the most potent xenoestrogen of all alkylphenols (Routledge and Sumpter, 1997). Ortho-substituted and short-chain alkylphenols have little or no xenoestrogen effect (Routledge and Sumpter, 1997).

Here we describe the qualitative analysis of the total alkylphenol matrix in produced water, together with the quantitative analysis of known alkylphenols in samples from various Norwegian offshore oil installations. For the qualitative analysis, large sample volumes and improved sample purification were used to achieve a high degree of analytical sensitivity and selectivity for detecting as many alkylphenol isomers as possible. Several approaches were then used to carry out identifications.

The first way to identify the unknown chromatographic peaks is to synthesise some of the alkylphenol isomers that are not currently available commercially. Having synthesised a few tertiary para-substituted long-chained alkylphenols, it may be possible to determine a significant part of xenoestrogens in produced water. However, this leaves the rest of the alkylphenol matrix unidentified.

Identification of alkylphenols in produced water may be facilitated by mapping all the unidentified isomers to provide a reliable basis for the analysis of hundreds of compounds for which standards do not exist. An efficient way of achieving such systematisation is by using retention indices. The retention index is the retention time of the analysed compound expressed relative to the retention times of a series of reference compounds. A method of 
alkylphenol retention indices (APRI) has been developed and applied to alkylphenols in produced water (Mjøs et al., 2006). It has been shown to be more robust for this purpose than the traditionally used Kovats indices, and allows accurate characterisation of alkylphenol isomers despite changes in chromatographic properties such as retention times. Thus, a systematisation of separate alkylphenol isomers becomes possible, resulting in unequivocal determination of any given alkylphenol isomer in various samples analysed under various chromatographic conditions, without the use of standards.

In addition to alkylphenols, thiophenols and naphthols have also been included in the analysis. These compounds have not previously been studied in produced water; however, their presence in oil has been shown (Beens and Tijssen, 1997; Thomson et al., 1997) and their toxicity towards bacteria or higher marine organisms investigated (Londry and Suflita, 1998; Falk-Petersen et al., 1985; Cajaraville et al., 1989). These two classes of compounds can undergo pentafluorobenzoyl derivatisation (Thomson et al., 1997) and may therefore be analysed by the same procedure as the one used for alkylphenols.

\section{Materials and Methods}

\subsection{Sampling strategy}

Large volumes (100 1) of produced water samples have been used to provide sufficient concentrations for analysing even the minor compounds. This was necessary, since many alkylphenols, particularly long-chain ones, are found only in small quantities in produced water. This study was not quantitative due to the novelty of the task, the absence of standards for establishing response factors, and because of the complicated multi-step procedure. However, smaller volumes of samples originating from 9 oil installations in the North and Norwegian Seas have been analysed for levels of the known alkylphenols by a previously described quantitative procedure (Boitsov et al., 2004), and the amounts of the unknown isomers have also been estimated. All together, the following 13 samples of produced water from 10 oil installations (see Fig. 1) in the Norwegian sector of the North Sea and the Norwegian Sea have been analysed in this work:

1. 2 large-volume (100 1) samples from Statfjord A and Statfjord B oil installations (sampled on January 28 and 29, 2005), to be used for qualitative analysis of even minute concentrations of unknown alkylphenols; 


\section{ACCEPTED MANUSCRIPT}

2. 9 regular volume $(100 \mathrm{ml})$ samples from all oil installations except Statfjord B (sampled on various dates in August 2005), to be used for quantitative analysis of known alkylphenols;

3. 2 regular volume $(100 \mathrm{ml})$ samples from Statfjord C and Oseberg C oil installations, without $\mathrm{HCl}$ added (sampled in August 2005, simultaneously with the samples to which $\mathrm{HCl}$ was added), to be used for checking the efficiency of the conservation procedure.

A blank sample of $100 \mathrm{ml}$ distilled water has been analysed together with regular volume samples for quantitative analysis purposes. All samples except the ones mentioned in point 3 above were added 1\% vol. of $\mathrm{HCl}$ :water 1:1 mixture for conservation immediately upon sample collection. After that, the samples were sent without airing to the laboratory and stored for 1 to 3 weeks at $+2^{\circ} \mathrm{C}$ in the dark until analysis.

(Figure 1)

\subsection{Chemicals and syntheses}

\subsubsection{Chemicals}

Pure standards (95-99.9\%) of 49 alkylphenols and 5 deuterated alkylphenols, 3 thiophenols and 2-naphthol were from Sigma-Aldrich (Oslo, Norway) and Chiron (Trondheim, Norway). Standard solutions were prepared in methanol. The derivatisation agent, pentafluorobenzoyl chloride (PFBC) was from Sigma-Aldrich. Solvents (methanol, hexane, tert-butyl-methyl ether, formic acid, toluene, isopropanol) were analytical grade from Merck (Oslo, Norway) and Arcus (Vestby, Norway). Sodium hydroxide $(\mathrm{NaOH})$, sodium bicarbonate $\left(\mathrm{NaHCO}_{3}\right)$ and hydrochloric acid $(\mathrm{HCl})$ were from Merck. Alcohols and alkenes used for syntheses were from Sigma-Aldrich (Oslo, Norway) and Alfa Aesar (Karlsruhe, Germany). The catalysts used for syntheses, $\mathrm{AlCl}_{3}$ and Amberlite IR-112 resin, were from Sigma-Aldrich (Oslo, Norway). The distilled water used was purified with NANOPURE Ultrapure Water Systems (USA). Solid-phase extraction Oasis ${ }^{\circledR}$ cartridges with anion-exchange MAX sorbent were from Waters (Milford, MA, USA).

\subsubsection{Syntheses}

The general procedure for the synthesis of para-substituted alkylphenols is well known, involving Friedel-Crafts reaction and certain catalytic and/or physical conditions to achieve 
130 the desired selectivity. Syntheses of long-chain tertiary alkylphenols have been carried out at

131 the University of Bergen according to the two following procedures. An acid-catalysed

132 reaction between phenol and substituted alcohols leads to pure single isomer products (Huston 133 and Hsieh, 1936); another one with phenol and an isoalkene as substrates and an ion-

134 exchange resin as catalyst yields a mixture of the corresponding ortho- or para-alkylphenol

135 isomers (Loev and Massengale, 1957). The first procedure was used for specific syntheses of

1363 para-tert-alkylphenols and the second one for non-specific syntheses of mixtures of various

137 tertiary alkylphenol isomers. Products were recrystallised consecutively from pure

138 dichloromethane and a hexane-dichloromethane 3:1 mixture and dried in oil vacuum (in case

139 of solid product), or the solvent was removed by rotor vapour (in case of liquid product).

140 Products were then analysed by GC-MS (full scan) and by $400 \mathrm{MHz}{ }^{1} \mathrm{H}$ nuclear magnetic

141 resonance (NMR) with deuterochloroform $\left(\mathrm{CDCl}_{3}\right)$ used as NMR solvent and reference. Only

142 pure products were analysed by NMR since NMR spectra of the mixtures could not be

143 resolved. The products of the syntheses are described in Table 1.

\subsection{Extraction and purification}

148 The $100 \mathrm{ml}$ samples were purified by filtration and solid-phase extraction, with subsequent 149 derivatisation by pentafluorobenzoyl chloride, according to the procedure described 150 previously (Boitsov et al., 2004). A method blank, made in distilled water, was processed together with the produced water samples. Quantitative data obtained for the produced water samples has then been corrected for blank values. The following detailed description of the experimental procedure concerns only the 1001 samples.

154 In this work we improved our regular purification procedure by introducing two 155 extra steps, gel-permeation chromatography (GPC) and normal-phase liquid chromatography

156 (NP-LC). GPC was used to remove small molecules like elementary sulphur and large 157 polymer compounds that could interfere with the analysis. The following NP-LC step 158 prevents an overlap of the signals from alkylphenols with those from other compounds 159 (Snyder et al., 2001). All alkylphenols were found in the same NP-LC fraction, well separated 160 from PAH and other compounds. Samples were then sufficiently clean to provide MS spectra 161 of good quality.

162 Each of the 1001 samples was first extracted with 2x50 ml dichloromethane (DCM)

163 for every 21 water, the extract volume was then reduced to approximately $0.5 \mathrm{ml}$ under gentle 
164 nitrogen gas flow in a water bath at $40^{\circ} \mathrm{C}$. The extracts were mixed together and the volume

165 was again reduced to approximately $5 \mathrm{ml}$. The two resulting extracts were then filtered, the

166 filters washed with DCM and the filtrates extracted with acetonitrile-hexane, and the polar

167 fraction was further fractioned by GPC, with the solvent exchanged to DCM. Both DCM and acetonitrile-hexane extraction efficiency was checked by analysing standard solutions of alkylphenols extracted in a similar way, achieving recoveries usual for this method (Boitsov et al., 2004).

173 Gel permeation chromatography (GPC) was used for the 1001 samples to remove sulphur and 174 other interfering compounds. The GPC cleanup was performed using systems from Gilson 175 (Gilson 232 autoinjector, injector Gilson 401 dilutor, Gilson 202 fraction collector, Gilson, 176 France) and Pharmacia (LKB 2150 HPLC pump, LKB 2252 LC controller, LKB 2144 177 fluorescence detector, Pharmacia LKB, Sweden). Two GPC columns from Waters (Envirogel 178 GPC cleanup $19 \mathrm{~mm}$ x $300 \mathrm{~mm}$ ) were used, coupled together using Gilson 232 autoinjector as 179 a switch vent. The setup and cleanup procedure are described in more detail elsewhere (Meier 180 et al., 2005). The elution was performed with DCM at a flow rate of $5 \mathrm{ml} / \mathrm{min}$. Samples were 181 subjected to GPC twice and the resulting purity of the alkylphenol fraction was confirmed by 182 GC-FID.

\subsubsection{NP-LC}

185 After GPC cleanup, the solvent was exchanged to hexane and samples were subjected to NP-

186 LC cleanup and fractionation. For this, the same Gilson fractioning system and Pharmacia 187 fluorescence detector as for GPC was used, but the NP-LC pump was from Shimadzu (LC-9A 188 with FCV-9AL low-pressure solvent mixer). The NP-LC column (150x4.6mm, LiChrosorb 189 60-5 Si) was from Varian (Middelburg, the Netherlands). Injection volume was $500 \mu 1$ at a 190 time. A gradient of 0 to $6 \%$ isopropanol in hexane was used as mobile phase. Fractions of 4 $191 \mathrm{ml}$ were collected from 0 to $30 \mathrm{~min}$.

19215 fractions were obtained, with alkylphenols being concentrated in fraction 8 (from 19314 to $16 \mathrm{~min}$ ), up to $97 \%$ according to GC-FID measurements. Other polar compounds eluted 194 in fractions 4-15, while PAH and other non-polar hydrocarbons eluted in fractions 1-3. All the 195 NP-LC fractions were then derivatised by pentafluorobenzoyl chloride as described 196 previously (Boitsov et al., 2004). 2 compounds in fraction 8 have been identified as belonging 197 to the naphthol class, one of them being 2-naphthol. 


\subsection{GC-MS analysis}

All analyses were performed on an Agilent 6890 GC system connected to an Agilent 5973 mass selective detector with either electron impact (EI) ionization, or negative chemical ionisation (NCI), in full scan mode, scanning from $\mathrm{m} / \mathrm{z} 50$ to 500 , or in selected ion monitoring (SIM) mode.

Samples of 0.11 were analysed in NCI SIM mode according to the quantitative procedure described earlier (Boitsov et al., 2004), routinely used for this purpose at our laboratory. The following deuterated internal standards were used for quantification: phenol$\mathrm{d}_{5}$, as reference for phenol; cresol- $\mathrm{d}_{8}$, as reference for cresols; 4-ethylphenol- $\mathrm{d}_{8}$, as reference for $\mathrm{C}_{2}$-alkylphenols; 4-propylphenol- $\mathrm{d}_{12}$, as reference for $\mathrm{C}_{3}-\mathrm{C}_{6}$ alkylphenols; 4-nonylphenol$\mathrm{d}_{4}$, as reference for $\mathrm{C}_{7}-\mathrm{C}_{9}$ alkylphenols.

Samples of 1001 were analysed non-quantitatively by both EI and NCI, both in SIM and full scan mode, as described below. The analyses of the EI mass spectra yield structure information while the NCI spectra lead to improved sensitivity and selectivity. $0.25 \mathrm{~mm}, d \mathrm{f}=0.25 \mu \mathrm{m}$, was used as analytical column. Helium (99.9\%) was used as carrier gas in $22 \mathrm{~cm} / \mathrm{s}$ constant flow mode. The samples ( $1 \mu$ l hexane solution) were injected in splitless mode and the split valve was opened after $2 \mathrm{~min}$. The GC program was optimised for alkylphenol analyses as described by Mjøs et al. (2006). The oven temperature was $60^{\circ} \mathrm{C}$ at injection. After $2 \mathrm{~min}$ the temperature was increased to $100^{\circ} \mathrm{C}$ by a temperature programming rate of $30^{\circ} \mathrm{C} / \mathrm{min}$, which was followed by a second rate of $2^{\circ} \mathrm{C} / \mathrm{min}$ to a final temperature of $260^{\circ} \mathrm{C}$. Dwell time per ion for all ions was $100 \mathrm{~ms}$. In SIM mode, the total chromatogram was divided into 5 windows (after solvent delay, $10 \mathrm{~min}$ ), each of these scanned for 4 to 5 selected ions to achieve better sensitivity. The corresponding parameters are shown in Table 2.

For naphthol analysis, the derivatised NP-LC fractions have been scanned in NCI mode for ion mass 338 , corresponding to pentafluorobenzoyl derivates of $\mathrm{C}_{1}$-naphthols, and analysed in EI mode. 2-naphthol was used as a standard for determining compounds of naphthol type in produced water.

For thiophenol analysis, the derivatised NP-LC fractions have been scanned in NCI mode for ion masses 318, 332, 346, 360, 374, 388, 402 and 416, corresponding to 


\section{ACCEPTED MANUSCRIPT}

232 pentafluorobenzoyl derivates of $\mathrm{C}_{1}-\mathrm{C}_{8}$ thiophenols, and analysed in EI mode. 4-Thiocresol, 4-

233 ethylthiophenol and 3,4-dimethylthiophenol were used as standards.

\section{3. Results and discussion}

236 3.1. Qualitative analysis: large-volume samples.

237

238

\subsubsection{Alkylphenols.}

239 A large number of alkylphenol isomers is present in produced water, only a portion of which 240 are identifiable from available standards (see Fig. 2). The number of non-identified 241 alkylphenols grows rapidly with alkyl chain length, as shown in Table 3.

(Figure 2)

Here we have employed a variety of methods in an attempt to characterize the unidentified alkylphenols. Large produced water samples (1001) from Statfjord A and Statfjord B platforms were used for the detailed, non-quantitative investigations described below. More than 350 compounds have been definitely or tentatively identified as alkylphenols with up to 8 carbon atoms in the alkyl substituents, by means of visual investigation of mass spectra. Of these, 305 peaks belonged to unidentified alkylphenols, which is apparent from m/z 195 (EI) belonging to the pentafluorobenzoate fragment, and the corresponding molecular peak for each alkylphenol; the rest were identified by means of the available standard. 2006), have been used to systematise all the detected alkylphenols. APRI can be calculated by the following equation (1):

$$
\mathrm{APRI}_{x}=n \frac{t_{\mathrm{R}(x)}-t_{\mathrm{R}(z)}}{t_{\mathrm{R}(z+n)}-t_{\mathrm{R}(z)}}+z
$$

257 where $t_{\mathrm{R}}$ is retention times of the compound of interest, $x$, and two para-substituted $n$ -

258 alkylphenols eluting on each side of the compound. $z$ represents the number of carbon atoms 259 in the alkyl chains of the para-alkylphenols eluting before $x$, and $n$ is the difference in the 260 number of carbon atoms between the two references. $z$ is zero if the first reference compound 261 is phenol. 
This systematisation provides a standard list of alkylphenols found in produced water, each compound on this list being assigned a unique number in accordance to its APRI value. Even though the precise isomeric structure of each particular compound remains unknown, this allows a determination of the same compound in any new sample on a similar stationary phase (for details, see Mjøs et al. (2006)). A selection of unidentified alkylphenols systematised in this way is shown in Section 3.2.

The biggest problem when attempting to identify the previously unidentified longchain alkylphenol isomers in produced water was the poor resolution of the peaks, despite the optimised GC conditions. Obviously, conventional GC-MS techniques do not provide sufficient data quality for this type of analysis, and supplementary or different techniques have to be used to achieve complete peak separation. In recent years, there have been substantial achievements in the development of methods for the mathematical resolution of overlapping chromatographic peaks (De Juan and Tauler, 2003). Most of these methods are multivariate procedures that reconstruct both chromatograms and spectra of the overlapping chromatographic peaks (Liang et al., 1993). It has been shown that with the proper selection of instrument parameters and pretreatment of data, it is possible to resolve overlapping peaks with very similar spectra (Mjøs, 2003). However, this is a rather time-consuming procedure when complex matrices such as produced water are studied, in which hundreds of peaks need to be resolved. An alternative solution to the problem is the use of a two-dimensional separation technique. Among these, GCxGC seems to be the most efficient technique that is suitable for analysis of complex samples (Dallüge et al., 2003). Thus, 40 isomers of 4nonylphenol present in technical nonylphenol mixture have been successfully separated by GCxGC coupled to time-of-flight mass spectrometer, although precise structural elucidation remained impossible since the samples were not derivatised (Moeder et al., 2006).

The mixtures of (ortho-, para-)hexyl- and heptylphenols were synthesised to determine xenoestrogenic para-isomers of long-chained alkylphenols in produced water and compare their relative amount to that of their less potent ortho- and meta-isomers. It has been observed for technical nonylphenol, representing a mixture of known nonylphenol isomers (Ruß et al., 2005), when derivatised with PFBC and analysed together with other standards,

291 that the majority of para-isomers have APRI values in the range of 7.1 to 7.7, eluting in a 292 narrow chromatographic "window" as a cluster of peaks. These are strongly branched 293 alkylphenols, while para- $n$-nonylphenol has APRI=9. Therefore, we expected the para294 isomers in the synthesised mixtures to elute closely together as well. However, their APRI 295 values were found to span a wide range, unlike those of technical nonylphenol, and the 


\section{ACCEPTED MANUSCRIPT}

samples therefore did not provide a basis for identification of clusters of para-substituted hexyl- or heptylphenols.

\subsubsection{Thiophenols.}

No compounds of thiophenol class have been found in the studied samples. The absence of thiophenols could be partly due to the pre-analysis sample preparation procedure that was not optimised for this type of compounds. However, the large volume of the analysed samples, 1000 times larger than the regular volume used for routine analysis of produced water at our laboratory, allows to suggest that the amounts of thiophenols in produced water are insignificant.

\subsubsection{Naphthols.}

Two compounds in the studied samples have been identified as belonging to the naphthol class (C1-naphthols, derivate molecular mass 338), one of them identified as 2-naphthol by means of the used standard. Qualitative results suggest that the concentrations of naphthol are rather limited, possibly 10 to 50 times smaller than the concentrations of alkylphenols of similar mass $\left(\mathrm{C}_{3}\right.$-alkylphenols, derivate molecular mass 330$)$, i.e. at $\mu \mathrm{g} / \mathrm{l}$ or below.

\subsubsection{Other compounds.}

A large number of unidentified compounds with molecular masses 328, 342, 356, 370 and 384 have been determined in the produced water samples. The same type of compounds have previously been observed in produced water from the Oseberg $\mathrm{C}$ oil installation (Boitsov et. al., unpublished results). The masses differ by 2 from $\mathrm{C}_{3}-\mathrm{C}_{7}$ alkylphenol pentafluorobenzoates; however, the relative amounts of the compounds are comparable to or even larger than those of the corresponding alkylphenols (Fig. 3). Similar compounds with masses differing by 4 from masses of alkylphenol derivates have also been observed.

(Figure 3)

A similarity between the mass spectra and chromatographic parameters of these compounds and those of alkylphenol derivates has given rise to a suggestion that the unknown compounds may be alkylphenols with unsaturated alkyl chains, i.e. alkenylphenols and alkynylphenols. Alkenylphenols are known to exist in nature, for instance in certain tropical plants (e.g., gibbilimbols, compounds with cytotoxic and antibacterial properties (Orjala et al., 1998)) and 
are also known to be formed as by-products during the photodegradation of alkylphenols or alkylation of phenol (Kohtani et al., 2005; Brodskii et al., 1973). Confirming the identity of the unknown compounds still remains to be done.

333

334

335

336

337

\subsection{Quantitative analysis: regular volume samples.}

Forty-nine alkylphenols have been identified and quantified in $100 \mathrm{ml}$ produced water samples from 9 oil platforms by means of commercially available alkylphenol standards or by those synthesised in our laboratory. It is worth pointing out that the previously described analytical method used in this study (Boitsov et al., 2004) allows for more precise measurements than some other commonly used methods not involving derivatisation of analytes, such as the one recommended to oil companies by the Norwegian Oil Industry Association (OLF) (OLF, 2003). The results presented below are thus different from those reported by Norwegian oil companies or by studies that use the OLF-endorsed method, which may result in a considerable underestimation of short-chain alkylphenol levels and an overestimation of long-chain alkylphenol levels (e.g., OLF, 2006).

The results from our study are given in Table 4, with APRI values given for each alkylphenol. The amounts of alkylphenols in the samples vary significantly from platform to platform, up to 3 orders of magnitude in some cases, thus reflecting a strong dependence of produced water composition on the origin of the oil. The difference in concentrations of longchained alkylphenols is, however, much smaller than that of phenol and short-chained alkylphenols, indicating that the endocrine-disrupting ability of produced water does not change as much from platform to platform as the overall toxicity.

\section{(Table 4)}

The main results of this study include a description of the levels of tertiary paraalkylphenols, the most potent xenoestrogens found in produced water. Significantly, the 3 tertiary para-alkylphenols, synthesised in the course of this work, 4-(1,1dimehtylbutyl)phenol, 4-(1,2,2-trimethylpropyl)phenol and 4-(1,1-dimethylpentyl)phenol have all been identified in produced water. The quantity of these compounds seemed to be relatively low, when compared to other alkylphenols of similar alkyl chain length. The total amount of the eight quantified para-tert-alkylphenols does not exceed $1.75 \mu \mathrm{g} / \mathrm{l}$ in any sample and is, as expected, heavily dominated by the least potent, but the most water-soluble compound, 4-tert-butylphenol. The largest amounts of the 8 xenoestrogens were found in 
364 discharges from Statfjord A, Statfjod C and Oseberg C platforms (see Table 4), which

365 remains true even if 4-tert-butylphenol is not taken into account. A recent bioassay study of

366 produced water from the same 10 platforms has also found samples from these 3 platforms to

367 have the highest xenoestrogen potency, up to an equivalent of $4.0 \mathrm{ng} / \mathrm{l} 17-\beta$-estradiol

368 (Tollefsen et al., 2007). This points to the crucial role that alkylphenols play in xenoestrogen

369 potency of produced water.

370 Earlier in vitro screening of produced water samples from the UK sector of the

371 North Sea has revealed even higher estrogen equivalents, up to $91 \mathrm{ng} / \mathrm{l} 17-\beta$-estradiol for

372 some samples (Thomas et al., 2004a). This significant xenoestrogen potency of produced

373 water has a clear endocrine-disrupting effect on marine biota like codfish (Meier et al., 2007);

374 however, upon release into the sea and consequent rapid dilution, the effect disappears. A risk

375 assessment modelling study has predicted no effect on codfish except in close proximity of

376 the discharge points (Myhre et al., 2004); this has now been confirmed both by in vivo

377 experiments (Meier et al., 2007) and field experiments studying codfish caged near the

378 discharge sites (Børseth and Tollefsen, 2004; Scott et al., 2006). The field experiments have

379 shown a weak induction of estrogen biomarker, vitellogenin, in the fish from cages put closest

380 to the oil platform, within $500 \mathrm{~m}$ from the point of discharge (Scott et al., 2006). Current

381 work reported no alkylphenols found in liver of wild North Sea codfish (Grøsvik et al., 2007).

382 Samples from two of the oil platforms, Statfjord C and Oseberg C, were tested for

383 stability when the conservation agent, $\mathrm{HCl}$, was not added. Two separate samples, one with

384 and one without $\mathrm{HCl}$, were obtained from each platform. No significant differences in the

385 concentrations were observed between the two samples in either case, except some for ortho-

386 substituted alkylphenols, due to the lowered efficiency of the method for these compounds

387 (Boitsov et al., 2004). This confirms the reliability of analysis, which is best suited for meta-

388 and para-substituted alkylphenols. Thus, alkylphenols in produced water seem to be stable

389 towards bacterial or other degradation when kept cool and in darkness in tightly sealed glass

390 bottles for up to 3 weeks.

391 The 4-nonylphenol that was found in some, but not all, samples in quantifiable

392 amounts (see Table 4) is thought to originate from sources other than produced water, due to

393 the omnipresence of nonylphenols in the laboratory environment (Meier et al., 2005).

394 An estimate of the amounts of unidentified alkylphenols has also been made for the

395 nine 100-ml samples. The established APRI system provided a confirmation of the presence

396 of the same compounds in different samples for all the unknown alkylphenols. However,

397 since these compounds are not available as standards, it was not possible to establish response 
398 factors for them, so a response factor of 1 was used. This cannot be regarded as an absolute

399 quantification; however, it may be helpful to give a rough estimate of the amount of the

400 compound present, and especially to compare relative amounts between produced water

401 samples from different locations. The total amounts for each molecular mass are shown in

402 Table 4, while concentration estimates for the selected separate unknown alkylphenols (given

403 as an average for the 9 locations) are shown in Table 5. All the unidentified C3-alkylphenols

404 are shown. For other alkylphenols, due to the large number of peaks (see Table 3), only two

405 of each are shown: those which, on average, appear in the largest amounts in the samples.

406

407

(Table 5)

408

409

\section{Conclusion}

410 In this work, an attempt has been made to investigate the previously unidentified alkylphenols

411 in produced water released into the sea from offshore oil installations. Two 1001 samples

412 from 2 locations in the North Sea have been used for a detailed qualitative analysis. Three

413 alkylphenols of high xenoestrogenic power were synthesised and identified in produced

414 water. A system of alkylphenol retention indices, APRI, developed for this work, has been

415 used to systematise all the observed alkylphenols, including the numerous unidentified ones.

416 This may facilitate further work to identify the unknown isomers. However, poor peak

417 separation precludes such analysis from being comprehensive, and other separation

418 techniques, such as GCxGC, are likely to be necessary. Other compounds, such as naphthols,

419 were also found in the samples, while thiophenols were not observed.

420 We also determined the concentrations of 52 alkylphenols found in produced water

421 from 9 offshore platforms in the North and Norwegian Seas, including the three newly

422 synthesised ones. While the levels of low-weight alkylphenols vary greatly from location to

423 location, only moderate differences have been observed in the levels of long-chained

424 alkylphenols. The results seem to support recent biological in vivo, in vitro, and field study

425 data in their conclusion that estrogenically induced endocrine-disruption in the marine biota,

426 due to produced water discharges, is only probable in the immediate vicinity of the point of

427 discharge. 


\section{5. Akcnowledgements}

430 We are grateful to Research Council of Norway for financial support, to Professor Jon

431 Songstad for valuable discussion and for laboratory facilities, to Dr. Nils Åge Frøystein for

432 the help with interpretation of NMR spectra, to Dr. Craig Morton for the help with the English 433 and to Julie Andersen for the help with creating the map. 


\section{ACCEPTED MANUSCRIPT}

434

435

436

437

438

439

440

441

442

443

444

445

446

447

448

449

450

451

452

453

454

455

456

457

458

\section{References}

Beens, J., and Tijssen, R. (1997). The characterization and quantitation of sulfurcontaining compounds in (heavy) middle distillates by LC-GC-FID-SCD. Journal of High Resolution Chromatography, 20, 131-137.

Boitsov, S., Meier, S., Klungsøyr, J., and Svardal, A. (2004). Gas chromatography-mass spectrometry analysis of alkylphenols in produced water from offshore oil installations as pentafluorobenzoate derivatives. Journal of Chromatography A, 1059, 131-141.

Brodskii, E.S., Lukashenko, I.M., Lebedevskaya, V.G., and Polyakova, A.A. (1973).

Determination of isomer and homolog composition of alkylphenols by molecular mass spectromery. Chemistry and Technology of Fuels and Oils, 9, 645-650.

Børseth, J.F., and Tollefsen, K.-E. (2004). Water column monitoring 2003 - summary report. Rogalandforskning report nr. 2004/039, RF, Stavanger, Norway, pp. 28.

Cajaraville, M.P., Marigomez, J.A., and Angulo, F. (1989). Stability of 1-naphthol in seawater solutions and its uptake by the marine prosobranch gastropod Littorina-Littorea $(L)$. Bulletin of Environmental Contamination and Toxicology, 42, 799-806.

Dallüge, J., Beens, J., and Brinkman, U.A.T. (2003). Comprehensive two-dimensional gas chromatography: a powerful and versatile analytical tool. Journal of Chromatography A, 1000, 69-108. 


\section{ACCEPTED MANUSCRIPT}

De Juan, A., and Tauler, R. (2003). Chemometrics applied to unravel multicomponent

460 processes and mixtures - Revisiting latest trends in multivariate resolution. Analytica

$461 \quad$ Chimica Acta, 500, 195-210.

462

463 Falk-Petersen, I.-B., Kjørsvik, E., Lønning, S., Naley, A.M., and Sydnes, L.K. Toxic

464 effects of hydroxilated aromatic hydrocarbons on marine embryos. (1985). Sarsia, 70, 1146516.

466

467 Grøsvik, B.-E., Meier, S., Westrheim, K., Skarphéðinsdóttir, H., Liewenborg, B., Balk, L., 468 and Klungsøyr, J. (2007). Condition monitoring in the water column 2005: Oil

469 hydrocarbons in fish from Norwegian waters. Institute of Marine Research report nr. 2470 2007, IMR, Bergen, Norway, pp. 33.

471

472 Huston, R.C., and Hsieh, T.Y. (1936). Condensation of aliphatic alcohols with aromatic 473 compounds in the presence of aluminium chloride. Journal of the American Chemical $474 \quad$ Society, $58,439-441$.

475

476 Kohtani, S., Hiro, J., Yamamoto, N., Kudo, A., Tokumura, K., and Nakagaki, R. (2005).

477 Adsorptive and photocatalytic properties of Ag-loaded BiVO4 on the degradation of 4-n478 alkylphenols under visible light irradiation. Catalysis Communications, 6, 185-189.

480 Liang, Y.-Z., Kvalheim, O., and Manne, R. (1993). White, gray and black multicomponent systems - a classification of mixture problems and methods for their quantitative analysis. Chemometrics and Intelligent Laboratory Systems, 18, 235-250. 


\section{ACCEPTED MANUSCRIPT}

Loev, B., and Massengale, J.T. (1957). Cation exchange resins as catalysts in the alkylation of phenols. Journal of Organic Chemistry, 22, 988-989.

\section{Londry, K.L., and Suflita, J.M. (1998). Toxicity effects of organosulfur compounds on} anaerobic microbial metabolism. Environmental Toxicology and Chemistry, 17, 11991206.

Meier, S., Klungsøyr, J., Boitsov, S., Eide, T., and Svardal, A. (2005). Gas chromatography-mass spectrometry analysis of alkylphenols in cod (Gadus morhua) tissues as pentafluorobenzoate derivatives. Journal of Chromatography A, 1062, 255-268.

Meier, S., Andersen, T.E., Norberg, B., Thorsen, A., Taranger, G.L., Kjesbu, O.S., Dahle, R., Morton, H.C., Klungsøyr, J., and Svardal, A. (2007). Effects of alkylphenols on the reproductive system of Atlantic cod (Gadus morhua L.) Aquatic Toxicology, 81, 207-218.

Mjøs, S.A. (2003). Spectral transformations for deconvolution methods applied on gas chromatography-mass spectrometry data. Analytica Chimica Acta, 488, 231-241.

Mjøs, S.A., Meier, S., and Boitsov, S. (2006). Alkylphenol retention indices. Journal of Chromatography A, 1123, 98-105.

Moeder, M., Martin, C., Schlosser, D., Harynuk, J., Górecki, T. (2006). Separation of technical 4-nonylphenols and their biodegradation products by comprehensive twodimensional gas chromatography coupled to time-of-oflight mass spectrometry. Journal of Chromatography A, 1107, 233-239. 
510 Myhre, L.P., Bausant, T., Sundt, R., Sanni, S., Vabø, R., Skjoldal, H.R., Klungsøyr, J.

511 (2004). Risk assessment of reproductive effects of alkylphenols in produced water on fish

512 stocks in the North Sea. Akvamiljø report AM-2004/018, RF-Akvamiljø, Stavanger,

$513 \quad$ Norway, pp. 76.

514

515 Nimrod, A.C., and Benson, W.H. (1996). Environmental estrogenic effects of alkylphenol 516 ethoxylates. Critical Reviews in Toxicology, 26, 335-364.

517

518 NPD. (2006). Norwegian Petroleum Directorate (NPD) press release 20/2006, 16.06.2006.

$519 \quad$ Available online at

520 http://www.npd.no/Norsk/Aktuelt/Pressemeldinger/2006/pressemelding_20_2006.htm (in

$521 \quad$ Norwegian).

522

523 OLF. (2003). Recommended guidelines for the sampling and analysis of produced water.

524 The Norwegian Oil Industry Association (OLF) Guidelines No. 85, pp 14.

525

526 OLF. (2006). Environmental report 2005. The Norwegian Oil Industry Association (OLF),

527 Stavanger, Norway, pp. 58. For the online version, as well as for field-specific data on

528 discharges, see http://www.olf.no/miljo/miljorapporter/?32711.

529

530 Orjala, J., Mian, P., Rali, T., and Sticher, O. (1998). Gibbilimbols A-D, cytotoxic and

531 antibacterial alkenylphenols from Piper gibbilimbum. Journal of Natural Products, 61,

532 939-941. 


\section{ACCEPTED MANUSCRIPT}

534

535

536

537

538

539

540

541

542

543

544

545

546

547

548

549

550

551

552

553

554

555

556

557

558

Routledge, E.J., and Sumpter, J.P. (1997). Structural features of alkylphenolic chemicals associated with estrogenic activity. Journal of Biological Chemistry, 272, 3280-3288.

Ruß, A.S., Vinken, R., Schuphan, I., and Schmidt, B. (2005). Synthesis of branched paranonylphenol isomers: occurrence and quantification in two commercial mixtures. Chemosphere, 60, 1624-1635.

Scott, A.P., Kristiansen, S.I., Katsiadaki, I., Thain, J., Tollefsen, K.-E., Goksøyr, A., and Barry, J. (2006). Assessment of oestrogen exposure in cod (Gadus morhua) and saithe (Pollachius virens) in relation to their proximity to an oilfield. In: Biological effects of contaminants in marine pelagic ecosystems. Eds. Hylland, K., Lang, T., and Vethaak, D. Special publication of Society of Environmental Toxicology and Chemistry (SETAC), pp. 329-339.

Snyder, S.A., Keith, T. L., Naylor, C.G., Staples, C.A., and Giesy, J.P. (2001).

Identification and quantitation method for nonylphenol and lower oligomer nonylphenol ethoxylates in fish tissues. Environmental Toxicology and Chemistry, 20, 1870-1873.

Thomas, K.V., Balaam, J., Hurst, M.R., and Thain, J.E. (2004a). Bio-analytical and chemical characterisation of offshore produced water effluents for estrogen receptor (ER) agonists. Journal of Environmental Monitoring, 6, 593-598.

Thomas, K.V., Balaam, J., Hurst, M.R., and Thain, J.E. (2004b). Identification of in vitro estrogen and androgen receptor agonists in North Sea offshore produced water discharges. Journal of Environmental Toxicology and Chemistry, 23, 1156-1163. 
560 Thomson, J.S., Green, J.B., and McWilliams, T.B. (1997). Determination of sulfides and

561 thiols in petroleum distillates using solid-phase extraction and derivatization with

562 pentafluorobenzoyl chloride. Energy \& Fuels, 11, 909-914.

563

564 Tollefsen, K.-E., Harman, C., Smith, A. and Thomas, K.V. (2007). Estrogen receptor (ER)

565 agonists and androgen receptor (AR) antagonists in effluents from Norwegian North Sea

566 oil production platforms. Marine Pollution Bulletin 54, 277-283. 


\section{ACCEPTED MANUSCRIPT}

567

568

569

570

571

572

573 alkylphenols).

574

575 Figure 3. Negative chemical ionisation (NCI), selected ion monitoring (SIM) ion

576 chromatograms of derivatised produced water sample from Statfjord B oil platform, for two

577 ion masses. Ion 358: C7-alkylphenol derivates. Ion 356: the unknown compounds. 


\section{ACCEPTED MANUSCRIPT}

578 Table 1. A description of the products of the syntheses.

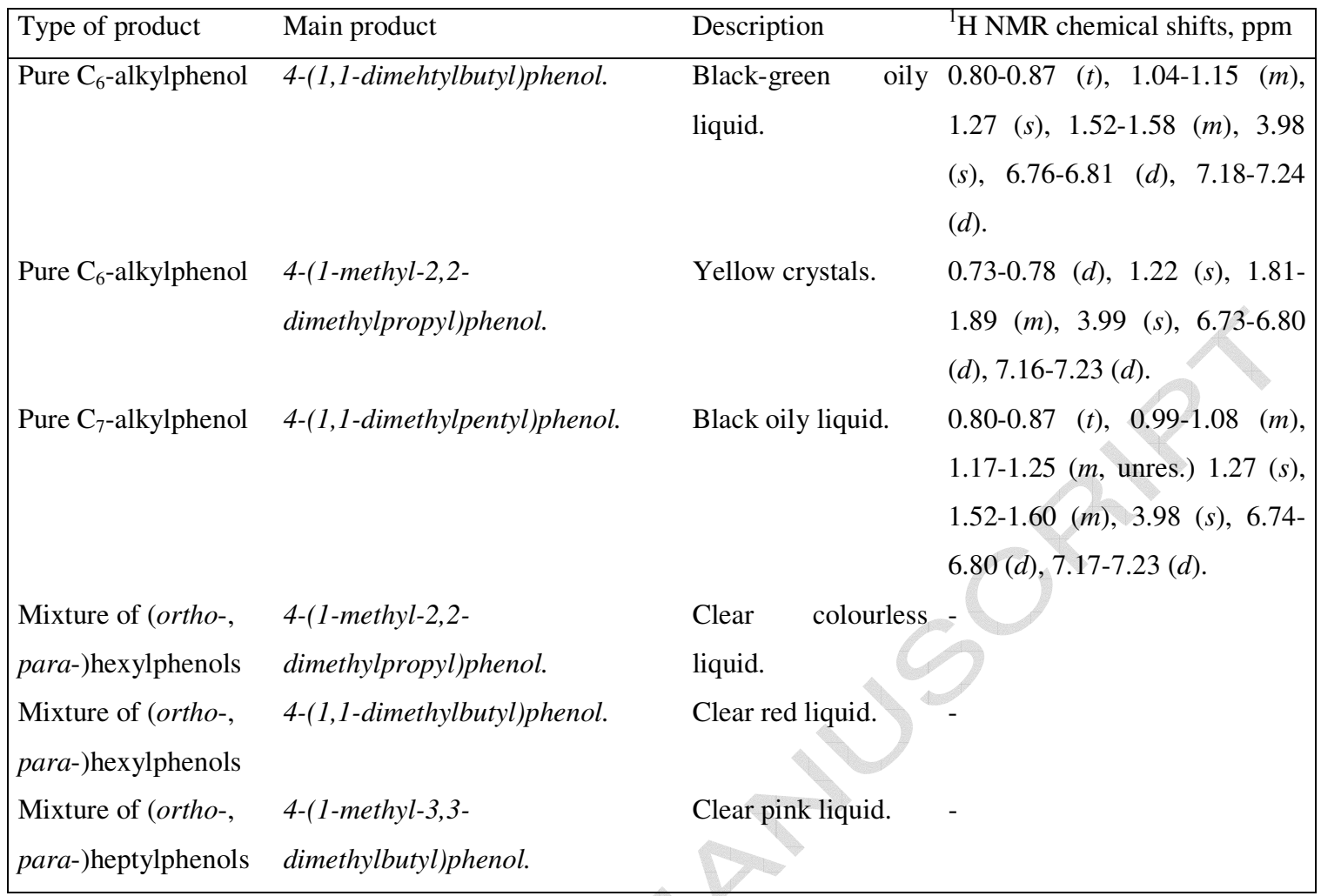




\section{ACCEPTED MANUSCRIPT}

580 Table 2. Selected ion monitoring (SIM) mode parameters used for alkylphenol analysis.

\begin{tabular}{lll}
\hline No. & Ion masses & Cycles/second \\
\hline 1 & $288,293^{*}, 302,309^{*}, 316$ & 1,91 \\
2 & $316,325^{*}, 330,341^{*}, 344$ & 1,91 \\
3 & $330,341^{*}, 344,358$ & 2,37 \\
4 & $330,344,358,372,386$ & 1,91 \\
5 & $372,386,400,414,418^{*}$ & 1,91 \\
\hline
\end{tabular}

581 * Ion masses of deuterated alkylphenols used as internal standards.

582

583

584 Table 3. Number of alkylphenol peaks in GC-MS chromatograms of produced water samples.

585

\begin{tabular}{|lcccccc|}
\hline $\begin{array}{c}\text { Alkylphenol } \\
\text { chain length }\end{array}$ & $\begin{array}{c}\text { Alkylphenol } \\
\text { derivate } \\
\text { mass }\end{array}$ & $\begin{array}{c}\text { Identified } \\
\text { alkylphenol } \\
\text { peaks }\end{array}$ & $\begin{array}{c}\text { Non-identified } \\
\text { alkylphenol } \\
\text { peaks }\end{array}$ & $\begin{array}{c}\text { Total } \\
\text { Of them } \\
\text { clusters }\end{array}$ & $\begin{array}{c}\text { Theoretically } \\
\text { possible }\end{array}$ \\
\hline C0 & 288 & 1 & 0 & 1 & 0 & 1 \\
C1 & 302 & 3 & 0 & 3 & 0 & 3 \\
C2 & 316 & 9 & 0 & 9 & 1 & 9 \\
C3 & 330 & 11 & 9 & 20 & 3 & 21 \\
C4 & 344 & 9 & 35 & 44 & 6 & 59 \\
C5 & 358 & 6 & 45 & 51 & 14 & 143 \\
C6 & 372 & 5 & 93 & 98 & 45 & 370 \\
C7 & 386 & 3 & 88 & 91 & 18 & 936 \\
C8 & 400 & 2 & 35 & 37 & 21 & 2287 \\
\hline Total & & 49 & 305 & 354 & 108 & 3829 \\
\hline
\end{tabular}

586 


\section{ACCEPTED MANUSCRIPT}

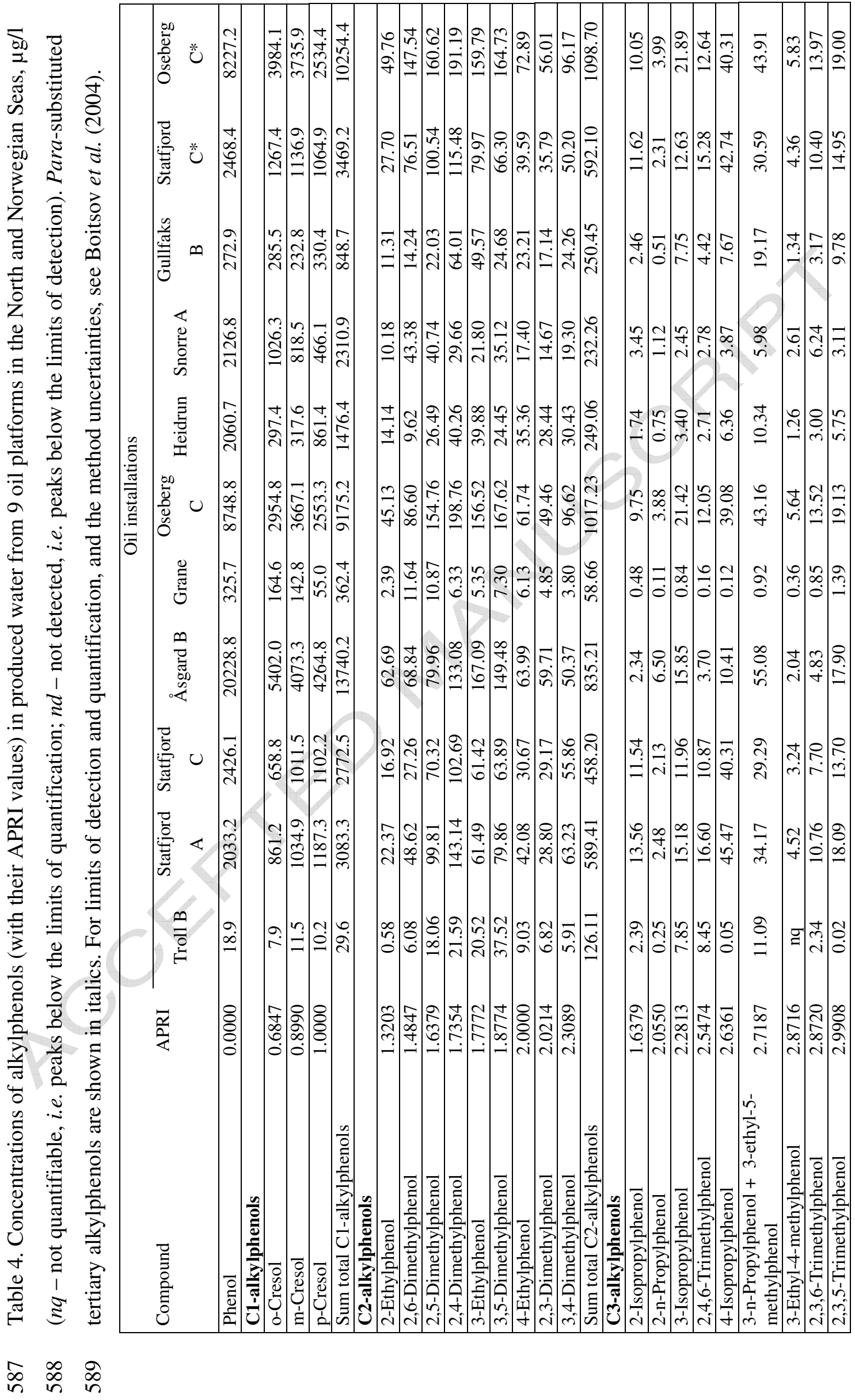




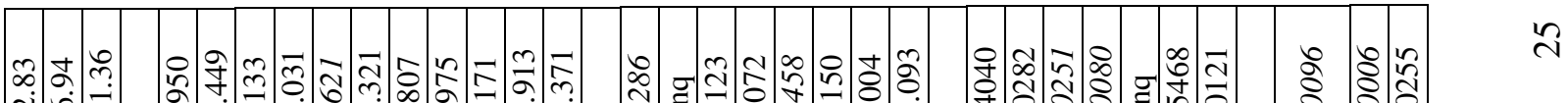

¿

$\therefore=$ ت.

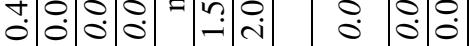

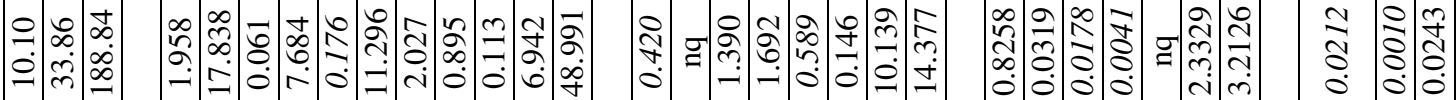

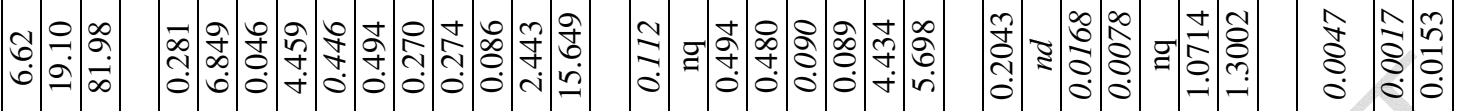

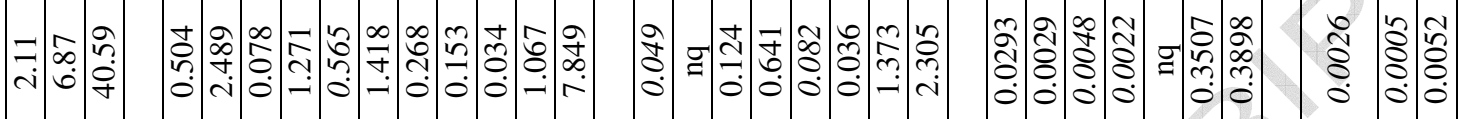

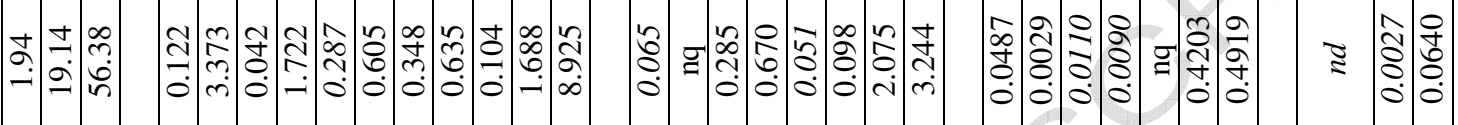

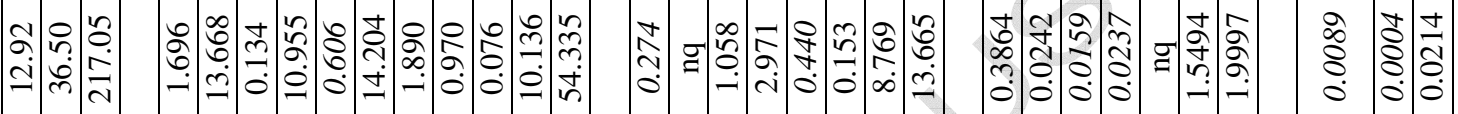

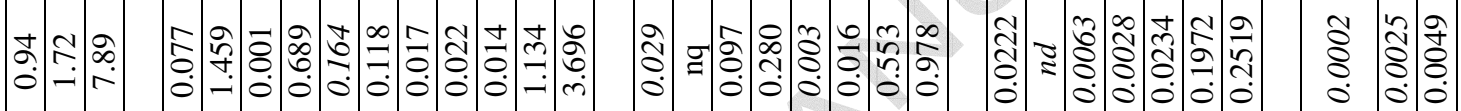

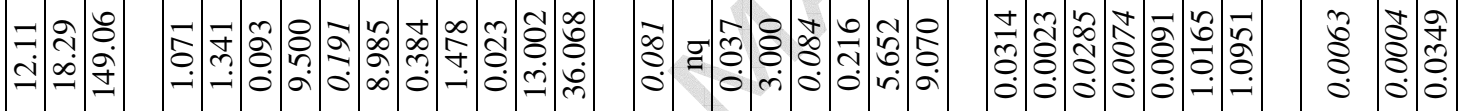

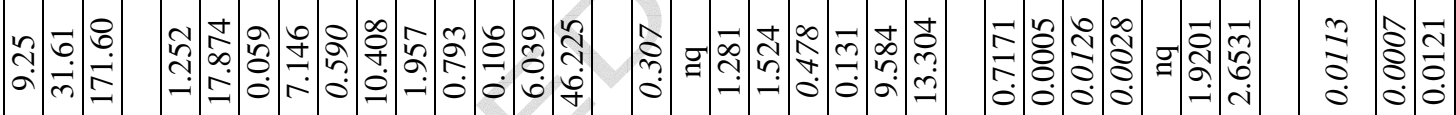

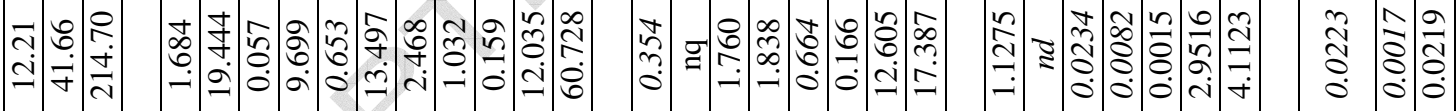

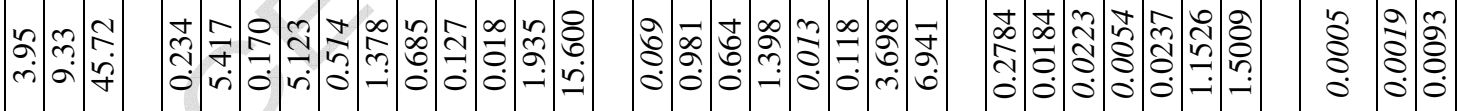

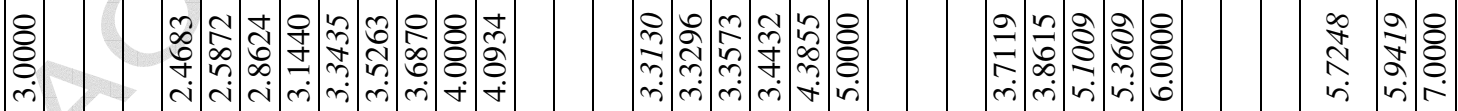

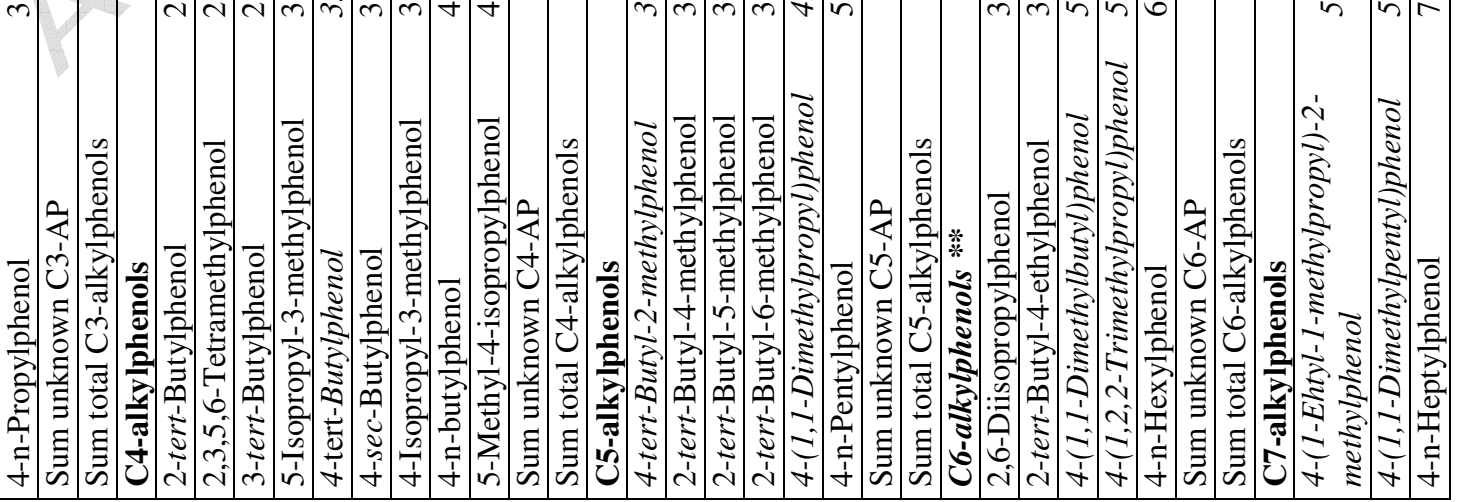




\section{ACCEPTED MANUSCRIPT}

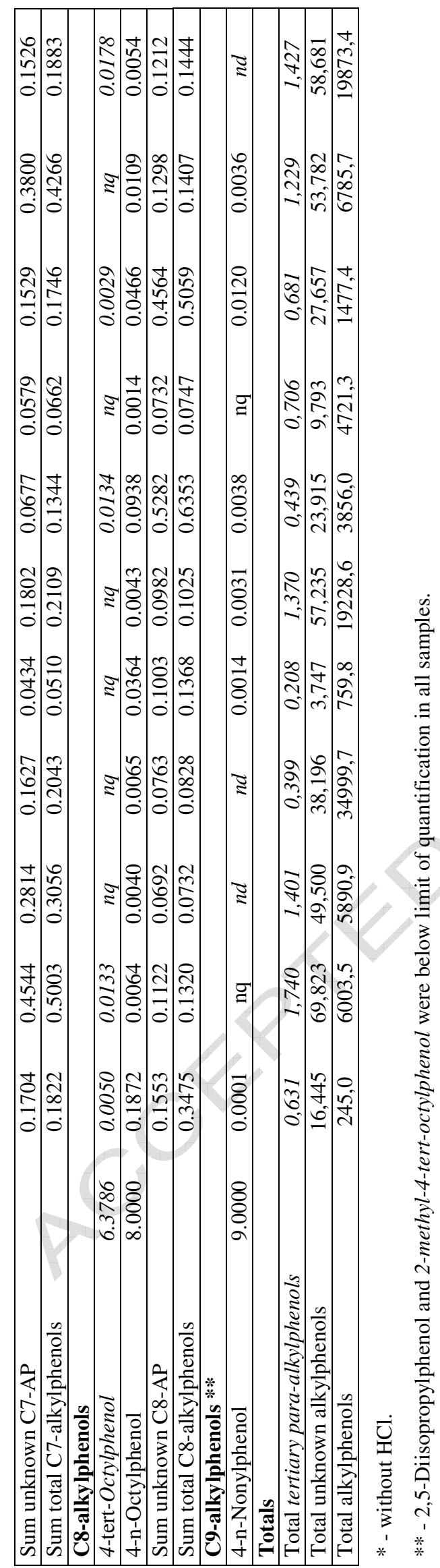




\section{ACCEPTED MANUSCRIPT}

593 Table 5. A selection of unidentified alkylphenols, found in produced water.

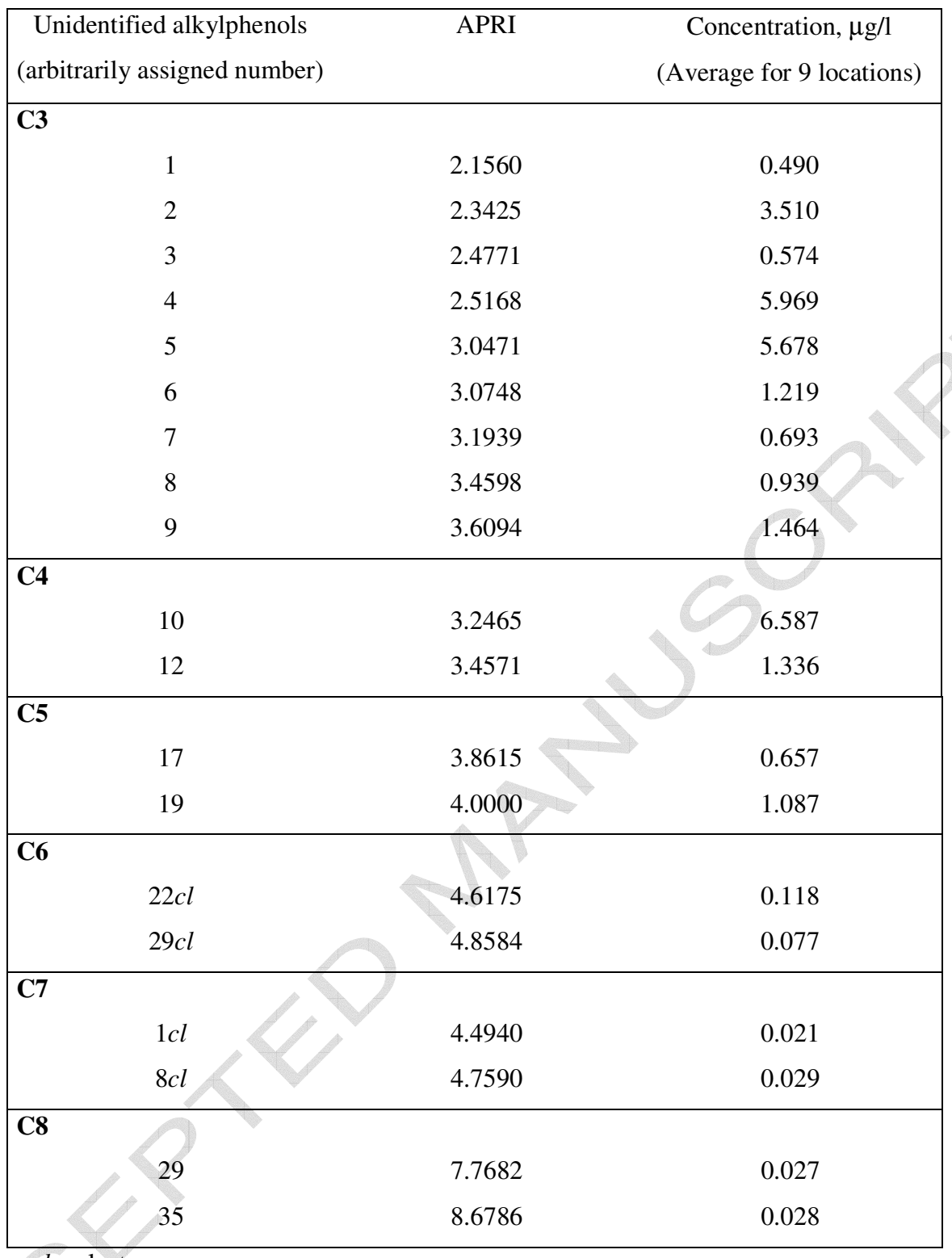

594

cl-cluster.

595 


\section{ACCEPTED MANUSCRIPT}

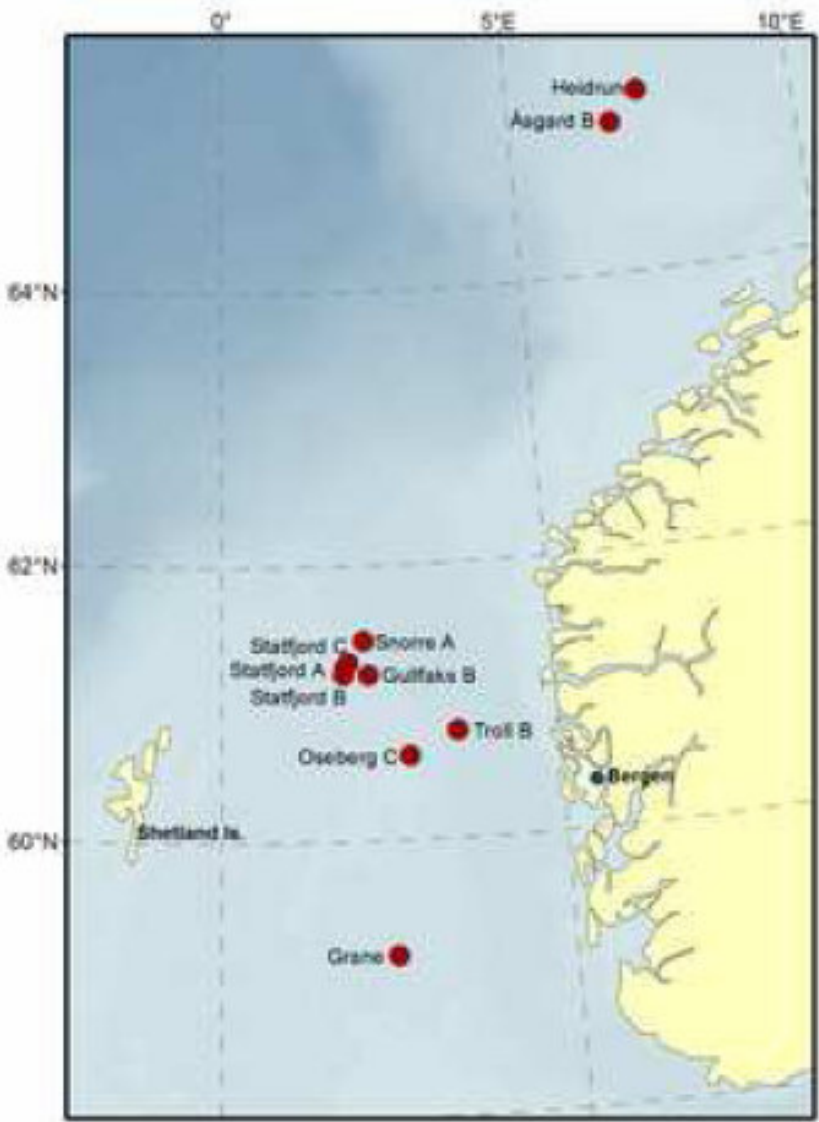

596

$597 \quad$ Fig.1 

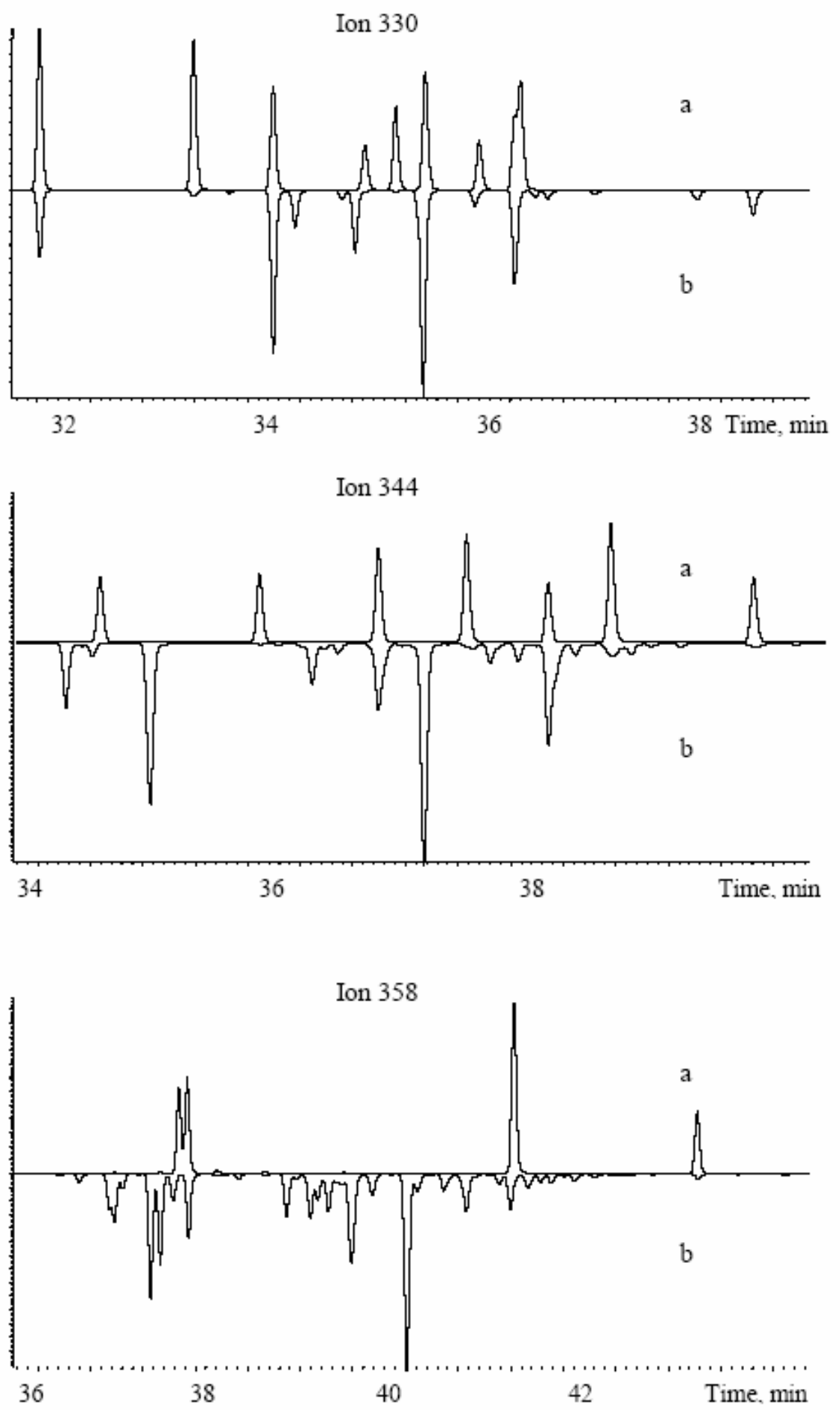

Figure 2. Negative chemical ionisation (NCI), selected ion monitoring (SIM) ion chromatograms of a standard solution of known alkylphenols (a) as compared to produced water samples (b) for ion masses 330 (C3-alkylphenols), 344 (C4-alkylphenols) and 358 (C5alkylphenols). 


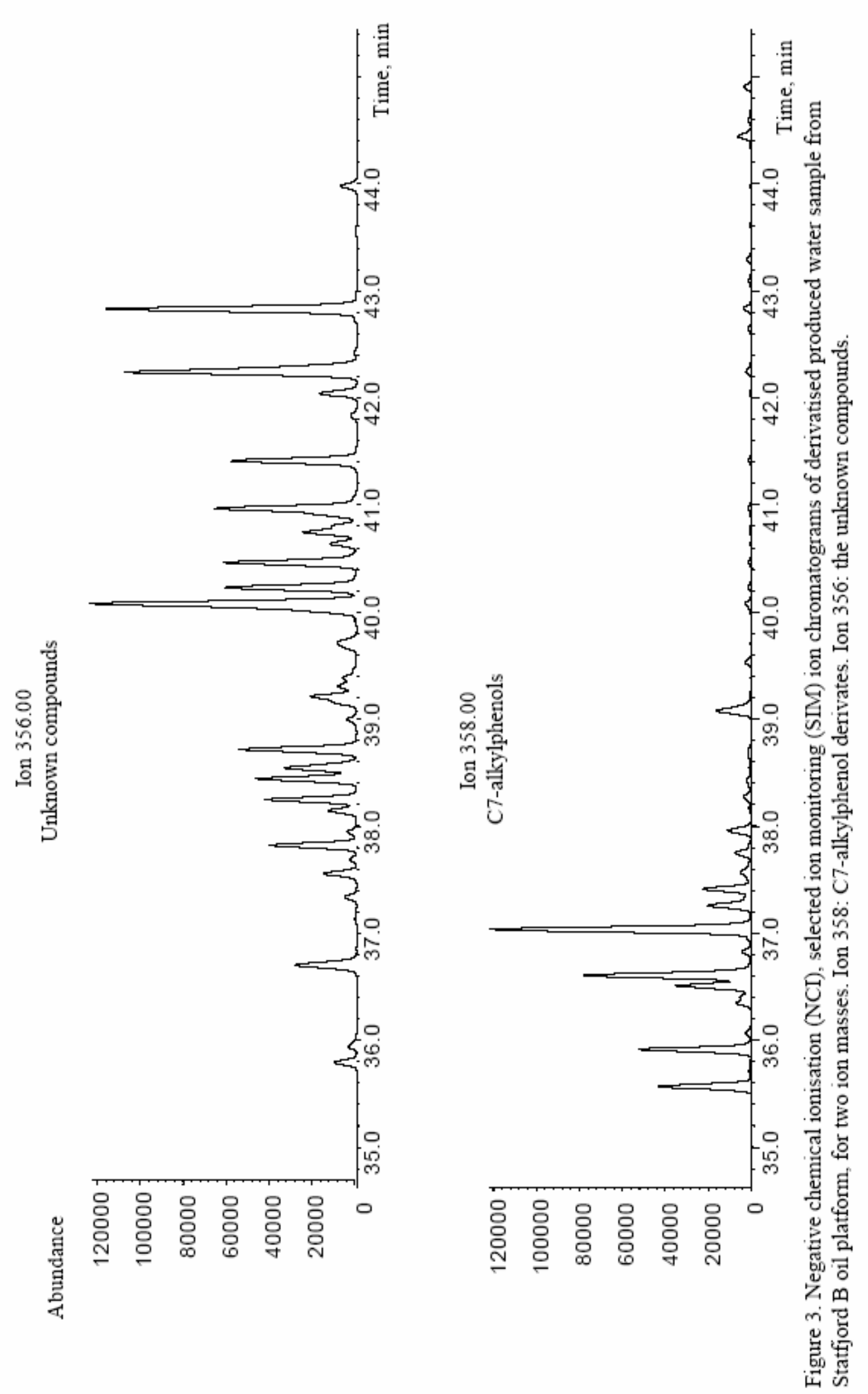

